\title{
The White Barley Mutant Albostrians Shows Enhanced Resistance to the Biotroph Blumeria graminis f. sp. hordei
}

\author{
Sanjay Kumar Jain, ${ }^{1}$ Gregor Langen, ${ }^{1}$ Wolfgang Hess, ${ }^{2}$ Thomas Börner, ${ }^{2}$ Ralph Hückelhoven, ${ }^{1}$ \\ and Karl-Heinz Kogel ${ }^{1}$ \\ ${ }^{1}$ Interdisciplinary Research Centre for Environmental Sciences, Institute of Phytopathology and Applied Zoology, \\ Justus-Liebig-University Giessen, Heinrich-Buff-Ring 26, D-35392 Giessen, Germany; ${ }^{2}$ Department of Biology, \\ Humboldt-University Berlin, Chausseestr. 117, D-10115 Berlin, Germany
}

Submitted 11 August 2003. Accepted 24 November 2003.

\begin{abstract}
We performed cytological and molecular analyses of the interaction between the biotrophic barley powdery mildew fungus Blumeria graminis f. sp. hordei and white and green leaves of the barley albostrians mutant. The leaves have the same nuclear genotype but differ from each other in respect to plastid differentiation. White leaves showed enhanced penetration resistance to $B$. graminis f. sp. hordei, associated with higher epidermal $\mathrm{H}_{2} \mathrm{O}_{2}$ accumulation beneath the appressorial germ tubes and protein cross-linking in papillae. Very low basal salicylic acid content was found in white leaves, which further confirmed that $\mathrm{H}_{2} \mathrm{O}_{2}$ accumulation and penetration resistance in barley are independent of salicylic acid. Expression analysis of stress and defense-related genes, including such being involved in reactive oxygen species production and cell death regulation, revealed stronger constitutive or pathogen-induced transcript accumulation in white leaves. We discuss the data on the basis of the finding that white albostrians leaves exhibit a supersusceptible interaction phenotype with the hemibiotrophic fungus Bipolaris sorokiniana.
\end{abstract}

Additional keywords: GDP-dissociation inhibitor, MLO, OXLP.

Plant mutants offer valuable biological variability in understanding plant processes and interactions. The albostrians mutant, derived from barley cv. Haisa, is such a mutant having different leaf phenotypes. The mutant was derived by X-rayinduced mutagenesis of a single recessive nuclear allele albostrians. The homozygous recessive allele albostrians blocks chloroplast development. This mutation of extranuclear hereditary factors is inherited purely maternally and is stable (Hagemann and Scholz 1962). The mutant produces entirely white and green leaves along with green and white striped leaves in various degrees. Both white and green leaves have the same nuclear genotype but differ from each other with respect to plastid differentiation. White leaves and white leaf parts contain undifferentiated plastids lacking internal membranes, which are photosynthetically inactive, have only trace amounts of chlorophylls, and lack $70 \mathrm{~S}$ ribosomes (Hess et al. 1994a). The transcript levels of many photosynthesis-associated chloroplast and nuclear genes are extremely low in white

Corresponding author: K.-H. Kogel; Fax: +49-641-9937499; E-mail: Karl-Heinz.Kogel@agrar.uni-giessen.de leaves (Hess et al. 1992; 1994b). In contrast, transcripts of many nuclear genes involved in the response against certain abiotic and biotic stresses were found to accumulate in much higher levels in white leaves (Hess et al. 1998).

In this study, we investigated the interaction of the albostrians mutant with the biotrophic fungal pathogen Blumeria graminis (D.C.) Speer f. sp. hordei Marchal, which causes powdery mildew on barley. Along with activation of defense-related genes (Gregersen et al. 1997), two main cytological responses are commonly recognized in the interaction of powdery mildew and barley. First, a papilla is formed directly beneath the site of attempted penetration. Second, a hypersensitive reaction (HR) is mounted, which is a cell death response of the attacked host cell, preventing the establishment of biotrophy (Koga et al. 1990). The successful penetration of a host cell is recognized by the formation of a haustorium, followed by formation of the elongated secondary hyphae (ESH) and fungal growth. One of the earliest events that occurs during hostpathogen interactions is generation of $\mathrm{H}_{2} \mathrm{O}_{2}$ and other reactive oxygen species (ROS), which play important roles in plant defense (Grant and Loake 2000; Hückelhoven and Kogel 2003). Enhanced production of $\mathrm{H}_{2} \mathrm{O}_{2}$ during oxidative burst has been shown to be involved in a number of plant defense processes. It leads to rapid oxidative cross-linking of cell wall components (Bradley et al. 1992; Thordal-Christensen et al. 1997), activation of defense genes (Wu et al. 1997), triggers HR that causes blocking of biotrophic pathogen development (Levine et al. 1994), and can reach higher concentrations directly toxic to pathogens (Peng and Kuc 1992). In barley-powdery mildew interactions, accumulation of ROS has been studied during both incompatible and compatible interactions (Hückelhoven and Kogel 1998; Hückelhoven et al. 1999; Thordal-Christensen et al. 1997).

The present investigation was initiated by the previous observation that albostrians white leaves, unlike green albostrians leaves and leaves from parent cv. Haisa, were extremely susceptible (supersusceptible) (Schäfer et al. 2004) to the toxin producing fungal pathogen Bipolaris sorokiniana. Here, we analyze effects of the albostrians mutation on fungal development and plant defense responses in green and white leaves. We show that enhanced resistance to $B$. graminis $\mathrm{f}$. sp. hordei is closely associated with enhanced papilla formation, $\mathrm{H}_{2} \mathrm{O}_{2}$ accumulation, enhanced expression of various defense genes previously implicated in powdery mildew resistance, as well as expression of the RAB-GDP-dissociation inhibitor $(G D I)$ gene. 


\section{RESULTS}

Cytological analysis of the interaction of albostrians white and green leaves with $B$. graminis f. sp. hordei.

We evaluated interaction phenotypes of white and green first leaves of albostrians, of white and green parts of striped leaves, and of wild-type cv. Haisa leaves at 24, 48, and 72 hours after inoculation (hai) with $B$. graminis f. sp. hordei race A6. Evaluation at 24 hai showed that, in $59 \%$ of the interaction sites, B. graminis f. sp. hordei failed to penetrate cells of white leaves whereas only $35 \%$ of the interaction sites in green leaves showed unsuccessful penetration (Figs. 1 and 2A). Autofluorescent phenolics were seen in both white and green leaves around appressoria associated with penetration failure (Fig. 2B). In white leaves, successful penetration as evident by haustorium and ESH formation took place in $36 \%$ of attacked cells, whereas corresponding value for the green leaves was $58 \%$. In green leaves, the frequency of haustorium formation remained at almost the same level through the time course up to $72 \mathrm{~h}$, whereas in white leaves, the fungus showed a tendency for a delayed development, thereby penetration frequency increased to about 49 (after $48 \mathrm{~h}$ ) and 54\% (after $72 \mathrm{~h}$ ) (Fig. 1). Frequency of nonpenetrated living cells with papilla formation was around $40 \%$ after $72 \mathrm{~h}$ in white leaves as compared with $25 \%$ in green leaves. The frequency of interaction sites showing epidermal HR of nonpenetrated cells (Fig. 2C) ranged from 7 to $12 \%$ in green leaves and from 3 to $6 \%$ in white leaves during the time course of the inspection. Interaction phenotypes of green leaves from albostrians and cv. Haisa were virtually identical. Both cv. Haisa and green albostrians leaves also showed a low frequency of mesophyll HR, which was not detected in white leaves (Fig. 1).

\section{$\mathrm{H}_{2} \mathrm{O}_{2}$ localization at interaction sites.}

$\mathrm{H}_{2} \mathrm{O}_{2}$ and other ROS accumulate in different amounts and patterns in susceptible and resistant barley lines after fungal attack (Hückelhoven and Kogel 2003). We analyzed the frequency of $\mathrm{H}_{2} \mathrm{O}_{2}$ at interaction sites in albostrians and cv. Haisa at 18, 24, and 48 hai (Fig. 3). After injection of diaminobenzidine (DAB), which polymerizes in the presence of $\mathrm{H}_{2} \mathrm{O}_{2}$ in a peroxidase-dependent manner, reddish-brown staining at interaction sites was observed. $\mathrm{H}_{2} \mathrm{O}_{2}$ accumulated beneath the primary germ tubes and appressoria (Fig. 2D through F), in anticlinal cell walls near penetration attempts, and in whole cells (Fig. $2 \mathrm{H})$. Successful penetration, as evident by formation of haustorial initials, did not provoke $\mathrm{H}_{2} \mathrm{O}_{2}$ accumulation (Fig. 2D). In white leaves, the frequency of $\mathrm{H}_{2} \mathrm{O}_{2}$ accumulation beneath appressoria (AGT) was between 23 (48 hai) and 34\% (18 and 24 hai) of all interaction sites (Fig. 3). In green leaves, these figures varied between 8 and $12 \%$. Approximately $10 \%$ of epidermal cells showed whole cell DAB-staining in epidermal cells in green leaves, compared with only $2 \%$ in white leaves (Fig. 3). Whole cell DAB staining in mesophyll was observed exclusively in green but not in white leaves at about $3 \%$ of interaction sites. There were similar frequencies of DAB-staining in the anticlinal cell walls (ACW) without staining at the AGT in both white and green leaves. However at 24 hai, there was a tendency for more ACW staining in green leaves, coinciding with more frequent fungal penetration (Hückelhoven et al. 1999).

\section{Protein cross-linking.}

Oxidative cross-linking of proteins has been demonstrated in papillae and HR cells of barley upon fungal attack (ThordalChristensen et al. 1997). Accordingly, we found Coomassie blue positive staining in papilla and HR cells of albostrians white and green leaves (Fig. 2I and J). The staining often was not associated with visible fungal structures, probably because they were washed away after sodium dodecyl sulfate (SDS) treatment, which is necessary to remove unbound proteins. Therefore, we were unable to thoroughly quantify oxidative protein cross-linking. However, given that the inoculation density was equal, visible judgment of Coomassie blue spots per microscopic field (by 20-fold magnification) suggested that there were more interaction sites with Coomassie staining in and around papillae in white leaves. This accords with the


Fig. 1. Frequency of cytological responses of white and green albostrians leaves as well as leaves from wild-type barley cv. Haisa at 24, 48, and 72 $\mathrm{h}$ after inoculation (hai) with Blumeria graminis f. sp. hordei race A6. Nonpenetrated living cells refer to interaction sites where fungus failed to penetrate the foremost epidermal cell. HAU (haustoria) and ESH (elongated secondary hyphae) refer to successful penetration of the cells. HR (hypersensitive reaction) refers to interaction sites where the epidermal cells show whole-cell autofluorescence, and MSHR (mesophyll-HR) refers to autofluorescence of mesophyll cells. Each column represents the average of 500 interaction sites on five leaves. Repetition of the experiments led to very similar results. 
finding that white leaves more frequently produce an oxidative environment at sites of attempted fungal penetration.

\section{Low salicylic acid contents detected in white leaves.}

We addressed the question whether total salicylic acid (SA) content differs in white and green albostrians leaves. Seven- day-old first leaves were inoculated with 50 conidia per $\mathrm{mm}^{2}$ of $B$. graminis f. sp. hordei, and SA content was measured at 24 and 48 hai. In green leaves, SA concentration was $400 \mathrm{ng}$ per gram of fresh weight and did not increase after inoculation. In white leaves, very low amounts of SA $(<50 \mathrm{ng}$ per gram of fresh weight) were detected in mock-inoculated


Fig. 2. Microphotographs of cytological responses of albostrians to Blumeria graminis f. sp. hordei. A through C, Defense responses expressed in epidermal cells in white leaves of albostrians after B. graminis f. sp. hordei infection. A, A fungal germling was stopped, and papillae formed beneath the primary germ tube and appressoria (arrows). Bar $=16 \mu \mathrm{m}, \mathbf{B}$, Same interaction site as shown in A. Phenolic compounds accumulated in and around papillae observed as autofluorescence under UV light excitation (arrows). Bar $=16 \mu \mathrm{m}, \mathbf{C}$, The nonpenetrated epidermal cell attacked by the appressorium (arrow) underwent a hypersensitive reaction (HR), as indicated by the whole-cell autofluorescence. Bar $=32 \mu \mathrm{m}$. D through $\mathbf{H}, \mathrm{H}_{2} \mathrm{O}_{2}$ accumulation patterns as observed by diaminobenzidine (DAB) staining in response to B. graminis f. sp. hordei. D, DAB-staining was not associated with successful penetration and formation of haustorial initial (arrow) $(B a r=16 \mu \mathrm{m}$ ) but was restricted to sites (arrowhead)also in $\mathbf{E}$, where fungus was prevented from penetration (arrow). $\mathrm{Bar}=12 \mu \mathrm{m}, \mathbf{F}$, Interaction site with four unsuccessful penetration attempts (arrowheads); each of them are associated with $\mathrm{H}_{2} \mathrm{O}_{2}$ accumulation (48 hai). Bar $=24 \mu \mathrm{m}, \mathbf{G}$, Rare interaction site in a white leaf, where delayed penetration (arrow, haustorial initial) of DAB associated papilla (arrowhead) occurred at 48 hai. $\mathrm{Bar}=16 \mu \mathrm{m}$. $\mathbf{H}$, Whole-cell $\mathrm{H}_{2} \mathrm{O}_{2}$ accumulation associated with epidermal hypersensitive cell death. Bar $=32 \mu \mathrm{m}$. I and $\mathbf{J}$, Coomassie blue staining for cross-linked proteins in papilla (arrow in I; Bar $=12 \mu \mathrm{m}$ ) and in $\mathrm{HR}$ cell $(\mathrm{J} ; \mathrm{Bar}=16 \mu \mathrm{m})$. $\mathbf{K}$, Micrograph of striped albostrians leaf after B. graminis $\mathrm{f}$. sp. hordei inoculation (96 hai). In the green leaf area (upper part), fungal mycelia developed normally, whereas in the white leaf area (lower part), fungal growth was considerably retarded. $\mathrm{Bar}=80 \mu \mathrm{m}$. 
leaves, and the SA concentration dropped upon inoculation below the detection limit (data not shown).

Gene expression patterns

in albostrians-B. graminis f. sp. hordei interactions.

We analyzed temporal expression patterns of genes, known to be differentially regulated in barley in response to $B$. graminis f. sp. hordei, in albostrians white and green first leaves at 0,24 , and 48 hai. Equal loading of RNA was achieved by adjusting $25 \mathrm{~S}$ and $18 \mathrm{~S}$ rRNA band intensities in gels (Zubko and Day 2002), since 23S and 16S rRNA bands
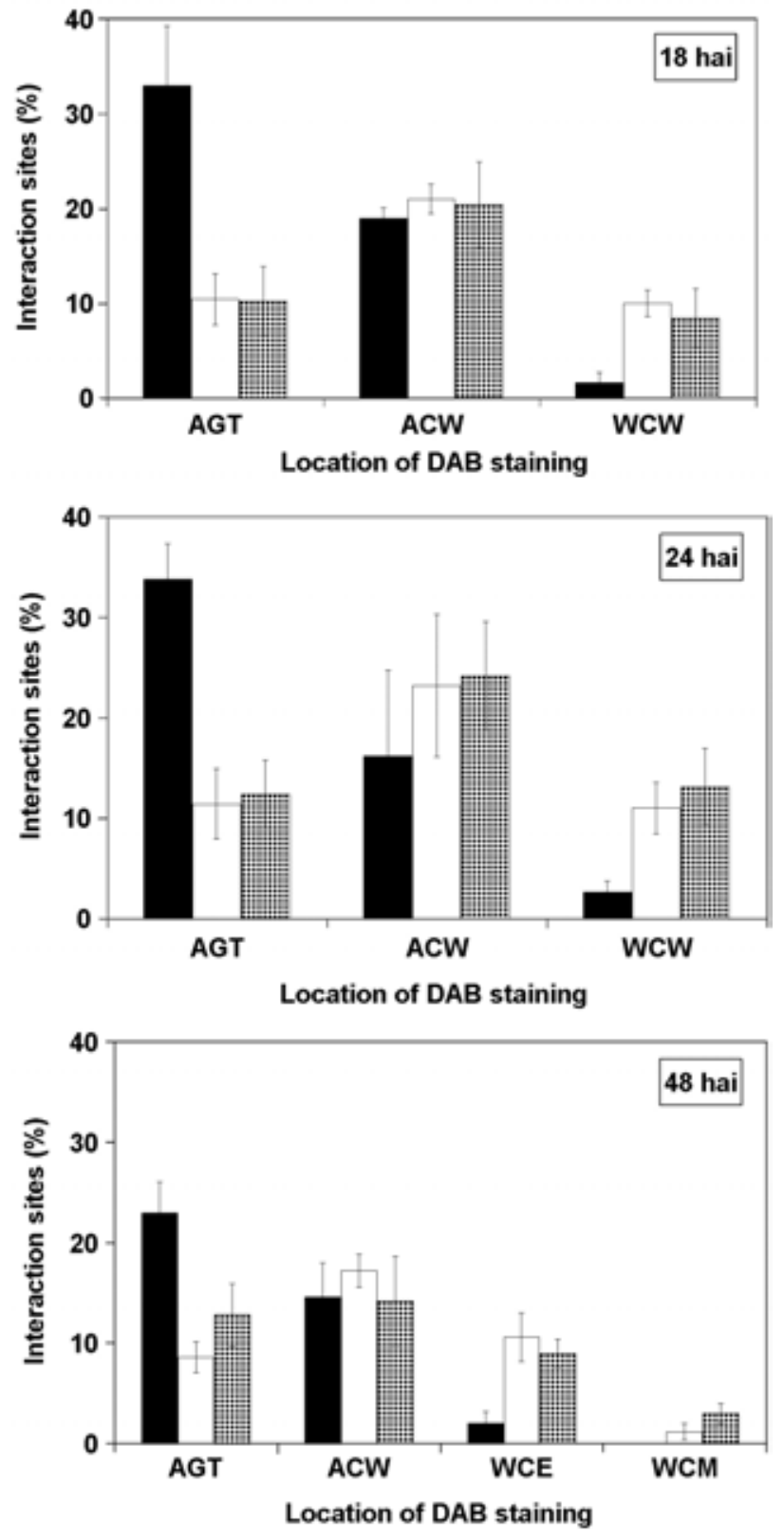

Albostrians White $\square$ Albostrians Green m Haisa

Fig. 3. $\mathrm{H}_{2} \mathrm{O}_{2}$ accumulation at interaction sites of white and green albostrians leaves as well as leaves from wild-type cv. Haisa at 18, 24, and $48 \mathrm{~h}$ after inoculation (hai) with Blumeria graminis f. sp. hordei race $\mathrm{A} 6 . \mathrm{H}_{2} \mathrm{O}_{2}$ accumulation, visualized by diaminobenzidine staining, was detected beneath appressorial germ tubes (AGT), in anticlinal cell walls close to penetration attempts (ACW), in whole epidermal cells (WCE), or in whole mesophyll cells (WCM). Each column represents the average of 500 interactions on five leaves (100 sites on each leaf). Repetition of the experiments led to very similar results. are lacking in white leaves. Higher gene transcript abundance was observed in white leaves for most of the genes (Fig. 4). The gene encoding basic pathogenesis-related $1 \mathrm{~b}$ protein $(P R$ $1 b)$, a marker for pathogenesis-related gene expression, was induced by 24 and 48 hai in both white and green leaves (Fig. 4). Similarly, expression of a phenylalanine ammonia-lyase gene (PAL), a 14-3-3 gene, and a gene for oxalate oxidase-like protein $(O X L P)$ was induced early upon fungal attack. The induction was always stronger in white leaves. Moreover, OXLP and 14-3-3 showed a greatly enhanced constitutive expression in white leaves.

We measured levels of putative anti- or proapoptotic genes. Expression of Bax inhibitor-1 (BI-1) and an aspartate protease (Asprot) were constitutively enhanced in white leaves. Upon



PR1b

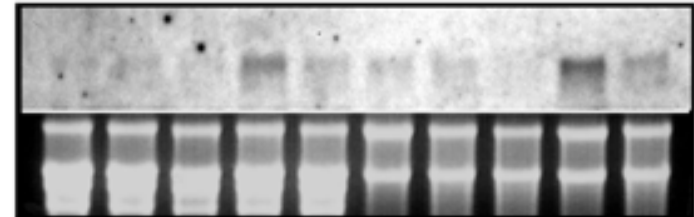

$P A L$

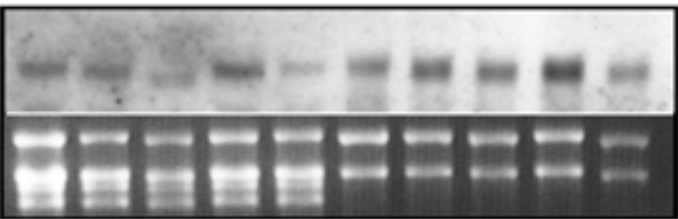

$14-3-3$

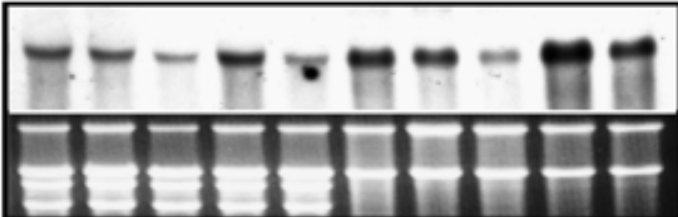

$O X L P$

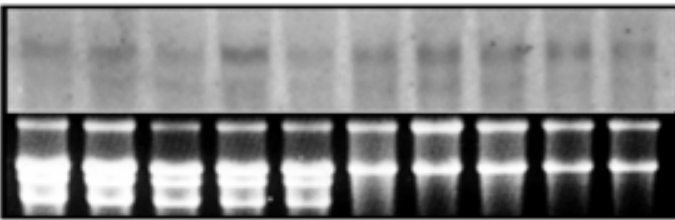

$B I-1$



Asprot

Fig. 4. Northern blot analysis of $P R-1 b$, phenylalanine ammonia-lyase $(P A L), 14-3-3$, oxalate oxidase-like-protein (OXLP), Bax inhibitor-1 (BI1), and aspartate protease (Asprot) transcript accumulation after inoculation with Blumeria graminis f. sp. hordei race A6 in white and green leaves of the barley albostrians mutant. Seven-day-old first leaves were inoculated with 50 conidia per square $\mathrm{mm}$, and leaves were harvested at 0 , 24 , and $48 \mathrm{~h}$ from mock-inoculated and inoculated plants. Total RNA was extracted, and $10 \mu \mathrm{g}$ and $5 \mu \mathrm{g}$ of total RNA for green and white leaves, respectively, were separated on denatured agarose gel and blotted onto nylon membranes. Blots were hybridized with digoxigenenin-labeled antisense probes. Ethidium bromide staining of the gel served as loading control. Independent experiments showed similar expression patterns. 
inoculation with B. graminis f. sp. hordei, BI-1 was slightly up-regulated only in the green leaves, while Asprot was induced only in the white leaves (Fig. 4). Expression of the powdery mildew resistance regulator $M l o$, cytosolic ascorbate peroxidase $(\mathrm{c} A P X)$, barley putative NADPH oxidase ( $p N A o x)$, and GDP dissociation inhibitor $(G D I)$ was analyzed by reverse transcription-polymerase chain reaction (RT-PCR) (Fig. 5). Total RNA was extracted from white and green leaves at 0,3 , $6,12,24$, and 48 hai. Template concentration was again adjusted using $25 \mathrm{~S}$ and $18 \mathrm{~S}$ rRNA. For final adjustment, the RTPCR expression pattern of a barley ubiquitin gene was taken as an additional constitutive control to correct variation in RNA template loading. As with several but not all other genes, expression of ubiquitin was higher in white leaves (Fig. 5). Similar to $B I-1$, expression of Mlo was slightly induced only in green leaves, though expression levels appeared constitutively higher in white leaves. Expression of cAPX was strongly induced by $B$. graminis f. sp. hordei in green leaves, though its expression level was constitutively high in white leaves, also. Expression of pNAox was up-regulated at early timepoints in both green and white leaves after $B$. graminis f. sp. hordei infection but was somewhat delayed in the white leaves. In contrast, expression of GDI was constitutively higher in white leaves and up-regulated in response to $B$. graminis f. sp. hordei in both types of leaves.

\section{DISCUSSION}

In the present study, we analyzed defense responses of white and green leaves of the barley mutant albostrians. We found that resistance to powdery mildew fungus is enhanced in white leaves. These results must be interpreted in the light of the finding that the same leaves are extremely susceptible to the hemibiotrophic fungus Bipolaris sorokiniana (Schäfer et al. 2004). A comparable ambivalence of defense characters in biotrophy and hemibiotrophy (or necrotrophy) has already been described in barley mutants with allelic variation at the Mlo locus (Jarosch et al. 1999; Kumar et al. 2001).

Resistance to B. graminis f. sp. hordei was associated with higher frequencies of $\mathrm{H}_{2} \mathrm{O}_{2}$ accumulation beneath the appressorial germ tubes, protein cross-linking in papillae, and a con-

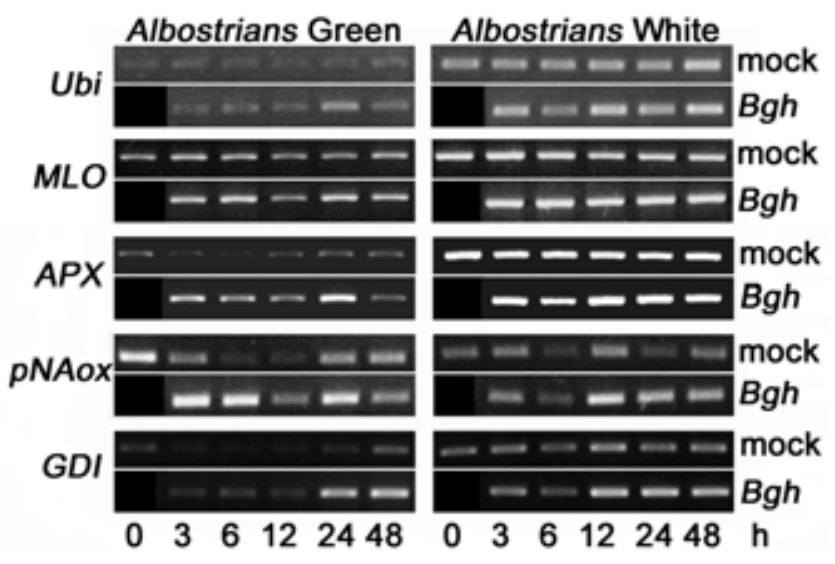

Fig. 5. Reverse transcription-polymerase chain reaction (RT-PCR) analysis of barley ubiquitin, $M L O$, cytosolic ascorbate peroxidase $(A P X)$, putative NADPH oxidase ( $p N A o x)$, and GDP-dissociation inhibitor $(G D I)$ in white and green leaves of the barley albostrians mutant after inoculation with Blumeria graminis f. sp. hordei race A6. Total RNA (4 $\mu \mathrm{g}$ for green and $2 \mu \mathrm{g}$ for white leaves) was used for first-strand cDNA synthesis using SuperScript reverse transcriptase. Expression levels of the genes were determined using $1 \mu \mathrm{l}$ of cDNA for PCR amplification with the gene-specific primers in a $25-\mu \mathrm{l}$ PCR reaction. Expression of ubiquitin ( $\mathrm{Ubi}$ ) was used as control for comparison over timepoints within green and white leaves. stitutively enhanced expression of various defense genes, such as those encoding a 14-3-3 protein and OXLP, the latter having been previously shown to be causally implicated in powdery mildew resistance (Schweizer et al. 1999).

Papillae in white and green leaves accumulated phenolic compounds, as evidenced by microscopic observation of autofluorescence (Fig. 2B), but significantly more nonpenetrated papillae were found in white leaves at any given timepoint (Fig. 1). At later timepoints (48 and 72 hai), a considerable proportion of papillae in white leaves were penetrated, as evidenced by an enhanced proportion of ESH (Fig. 1). This indicates that papilla formation per se may not be sufficient to mediate penetration resistance to $B$. graminis $\mathrm{f}$. $\mathrm{sp}$. hordei. The tendency of delayed penetration may be due to lack of photosynthetic activity and limited supply of nutrients in white leaves. This may ultimately result in slow development of mycelium (Fig. 2K) and extremely rare formation of B. graminis f. sp. hordei pustules, development of which was delayed by 1 or 2 days (data not shown). Consistently, delayed development of B. graminis on white (albino) leaves from Triticum timopheevii and Hordeum vulgare (cv. Trebi I) has been previously demonstrated (Nashaat and Moore 1992; Shioji et al. 1982). A lower frequency of interaction sites with HR of nonpenetrated epidermal cells were observed in white leaves (Fig. 1), probably reflecting a higher penetration resistance of white leaves. Notably, white leaves showed more epidermal HR against the hemibiotrophic Bipolaris sorokiniana (Schäfer et al. 2004). In contrast to our results, Nashaat and Moore (1992) observed a lower percentage of papillae in response to the wheat powdery mildew fungus on albino leaves of Triticum timopheevii. These authors suggested that low photosynthetic activity in white leaves may have reduced the efficiency of papilla formation. Thus, enhanced penetration resistance in white albostrians leaves may be specific for the albostrians mutation. This notion is supported by the finding that white leaves show a higher number of sites with $\mathrm{H}_{2} \mathrm{O}_{2}$ accumulation at papillae, clearly suggesting an active defense mechanism (Fig. 3).

Protein cross-linking in and around papillae and in HR cells, as evident by a positive Coomassie blue stain (Fig. 2I and J), is suggested to be $\mathrm{H}_{2} \mathrm{O}_{2}$-mediated (Thordal-Christensen et al. 1997). The emergence of immobile proteins in papillae was more intense and frequent in white leaves, thus correlating with a higher frequency of $\mathrm{H}_{2} \mathrm{O}_{2}$ accumulation and higher penetration resistance (Figs. 1 and 3).

Previous studies have shown that SA does not accumulate in barley after powdery mildew inoculation (Hückelhoven et al. 1999; Vallelian-Bindschedler et al. 1998). Moreover, $\mathrm{H}_{2} \mathrm{O}_{2}$ generation, formation of effective papillae, and HR are independent of SA accumulation (Hückelhoven et al. 1999). In agreement with these findings, SA did not accumulate in response to B. graminis f. sp. hordei. Interestingly, white leaves showed very low amounts of basal SA, though they more frequently accumulated $\mathrm{H}_{2} \mathrm{O}_{2}$ in papillae. The pathway of SA synthesis in plants is not completely elucidated. SA is suggested to be synthesized from either phenylalanine, chorismate, or both (Shah 2003). White leaves of albostrians contain higher amounts of phenylalanine but drastically reduced amounts of the chorismate-precursor shikimate (data not shown), i.e., SA might indeed be formed from chorismate via isochorismate in barley. Many studies have shown positive correlation between $P R-1$ transcript induction and SA content (Nawrath and Métraux 1999). However, expression of genes encoding basic PR1 proteins have been shown to be induced by jasmonic acid and ethylene and, in some cases, repressed by SA (Santamaria et al. 2001). In our experiments, pathogeninduced expression of basic $P R-1 b$ that apparently contributes in barley to penetration resistance against $B$. graminis f. sp. 
hordei (Schultheiss et al. 2003) was higher in white leaves (Fig. 4). This suggests that background resistance of white leaves and the activation of $P R-1 b$ in response to $B$. graminis $\mathrm{f}$. sp. hordei do not require SA.

Along with a constitutively enhanced gene expression level and in accordance with the higher resistance, we found in white leaves a stronger increase of defense-related genes $P A L$, OXLP, and 14-3-3. The role of PAL (Boyd et al. 1994; Clark et al. 1994; Dixon and Paiva 1995) and OXLP (Schweizer et al. 1999; Wei et al. 1998) in plant defense has been demonstrated previously. Early and strong expression of $O X L P$ was found in barley lines resistant to penetration by $B$. graminis f. sp. hordei (Hückelhoven et al. 2001). Thus, stronger expression of $O X L P$ in white leaves (Fig. 4) agrees with these results and is one possible explanation for the higher resistance of these leaves.

The 14-3-3 proteins form a conserved gene family in animals and plants and have been associated with several stress responses. Their role in plant defense is proposed to be in signal transduction and gene regulation (Finnie et al. 1999; Roberts 2003). Induction of $14-3-3$ expression in response to $B$. graminis $\mathrm{f}$. $\mathrm{sp}$. hordei results in an activation of the plasma membrane $\mathrm{H}^{+}$-ATPase in barley epidermal cells (Finnie et al. 2002). Modulation of plasma membrane $\mathrm{H}^{+}$-ATPase activity has been reported to be involved in defense and general stress signaling in plants. A role for the activation of the $\mathrm{H}^{+}$-ATPase in the induction of the HR of barley to B. graminis f. sp. hordei has been suggested (Zhou et al. 2000).

We found increased expression of the Asprot gene in response to $B$. graminis f. sp. hordei in white leaves (Fig. 4). The gene was implicated in developmentally regulated barley cell death (Runeberg-Roos and Saarma 1998), and expression of Asprot was up-regulated after powdery mildew infection in barley lines showing either penetration resistance or mesophyll cell death but not in susceptible barley (Hückelhoven et al. 2001).

A striking result of this study is the finding that expression of $B I-1$ and $M l o$ is constitutively enhanced in white leaves (Fig. 5). Both genes exert cell death and defense-suppressing capacity, and their expression can be associated with biotic and abiotic stresses (Kawai et al. 1999; Piffanelli et al. 2002, Sanchez et al. 2000). BI- 1 has been described as a regulator of cell death, and its expression is up-regulated after pathogen inoculation and wounding (Hückelhoven et al. 2001; Kawai et al. 1999; Sanchez et al. 2000). Overexpression of barley BI-1 induces supersusceptibility to $B$. graminis f. sp. horde $i$ and breaks mlo-mediated penetration resistance (Hückelhoven et al. 2003). Mlo is a negative regulator of defense reactions (penetration resistance, necrosis) to $B$. graminis f. sp. hordei and mutations in Mlo confer race-nonspecific resistance to the fungus. A transiently increased expression of $M l o$ has been shown in response to B. graminis f. sp. hordei and Magnaporthe grisea infection and in response to abiotic stresses such as wounding and paraquat treatment (Piffanelli et al. 2002). We detected slightly induced Mlo expression by $6 \mathrm{~h}$ after $B$. graminis f. sp. hordei inoculation in green leaves. Strikingly and unexpectedly, high Mlo and $B I-1$ expression in white leaves was insufficient to induce enhanced susceptibility to $B$. graminis f. sp. hordei, though overexpression of Mlo (Kim et al. 2002) and BI-1 (Hückelhoven et al. 2003) in barley epidermal cells greatly enhanced cell accessibility for this fungus. In a control experiment, we confirmed that transient overexpression of both $B I-1$ and MLO in white leaves resulted in increased susceptibility to B. graminis f. sp. hordei (data not shown). Thus, MLO and BI-1 are obviously functional in white leaves, and enhanced resistance of albostrians seems to be independent of BI-1 and MLO.

Interestingly, we detected a high frequency of $\mathrm{H}_{2} \mathrm{O}_{2}$ accumulation at epidermal sites of attempted infection but a strongly reduced potential to accumulate $\mathrm{H}_{2} \mathrm{O}_{2}$ in mesophyll tissue of white leaves (Schäfer et al. 2004). One of the major $\mathrm{H}_{2} \mathrm{O}_{2}$ scavenging enzymes in the plant is ascorbate peroxidase, which is found throughout the cell (Jespersen et al. 1997). Increased expression and activity of a $c A P X$ isoform has been detected upon $B$. graminis f. sp. hordei infection, especially at late timepoints of the compatible interaction (Burhenne and Gregersen 2000; Hückelhoven et al. 2001). Notably, strong $c A P X$ expression in white leaves did not compromise apoplastic $\mathrm{H}_{2} \mathrm{O}_{2}$ accumulation. One reason for this could be tissuespecific or posttranscriptional regulation of $c A P X$ (Mittler et al. 1998).

NADP $(\mathrm{H})$ oxidase generates superoxide anions $\left({ }^{\circ} \mathrm{O}_{2}^{-}\right)$that become readily dismutated into $\mathrm{H}_{2} \mathrm{O}_{2}$ either spontaneously or by superoxide dismutase (Grant and Loake 2000). There is increasing evidence that, in the barley-powdery mildew interaction, ${ }^{\circ} \mathrm{O}_{2}^{-}$accumulation at infection sites, in contrast to $\mathrm{H}_{2} \mathrm{O}_{2}$, is associated with successful cell wall penetration rather than defense (Hückelhoven and Kogel 2003). In accordance with these findings, a pathogen-induced early increase of NADP(H) oxidase expression was found in green leaves, while white leaves showed a delayed response of $\operatorname{NADP}(\mathrm{H})$ oxidase expression. Notably, this late response correlates with delayed penetration events in white leaves.

GDI is one of the regulatory proteins of the RAB GTPase cycle involved in vesicular membrane traffic regulation (Pfeffer et al. 1995; Ueda et al. 1998). Involvement of RAB proteins and vesicle transport in plant defense has been suggested (Bogdanove and Martin 2000; Collins et al. 2003; Cooper et al. 2003; Sano and Ohashi 1995). Hence, regulation of RABGDI might be critical for effective defense. In rice, expression of two RAB-specific GDI genes (OsGDIs) was substantially induced after treatments with an elicitor of $M$. grisea (Kim et al. 1999), suggesting GDI may have an important role in the plant response to fungal infection. We found a strong induction of the barley GDI to B. graminis f. sp. hordei inoculation, and in accordance with an earlier report (Hess et al. 1998), a stronger overall expression in white leaves (Fig. 5). Single-cell gene silencing of barley GDI slightly enhanced susceptibility of white leaves to B. graminis f. sp. hordei (data not shown), suggesting that GDI might be one element of enhanced resistance. The mechanism of RAB and GDI function in resistance is the subject for further research, since plants have many RAB proteins but many fewer RAB-GDIs (Kim et al. 1999; Vernoud et al. 2003).

\section{MATERIALS AND METHODS}

Plant material, pathogen, and inoculation.

The barley (Hordeum vulgare L.) mutant albostrians was derived from spring barley cv. Haisa by irradiation (Hagemann and Scholz 1962). This mutant produces plants with white, green, and white and green striped leaves, respectively. Seedlings were grown in a growth chamber at $18^{\circ} \mathrm{C}$ with $60 \%$ relative humidity and a photoperiod of $16 \mathrm{~h}$.

Race A6 of Blumeria graminis f. sp. hordei was used for inoculation of first leaves (Wiberg 1974). For cytological analyses, a conidial density of about 15 to 20 spores per square $\mathrm{mm}$, and for gene expression and salicylic acid measurement, 50 conidia per square $\mathrm{mm}$ were used.

\section{Microscopy for host-pathogen interactions.}

Seven-day-old first leaves were inoculated on the adaxial surface with 15 to 20 conidia per square $\mathrm{mm}$. Leaves were harvested at 24, 48, and 72 hai. Leaf fixation and clearing, bright field microscopy, and fluorescence microscopy were performed as described by Hückelhoven and Kogel (1998). Quan- 
tification of penetration resistance, HR, and penetration was performed in 100 interactions per leaf. Because the rate of fungal penetration of barley leaf epidermal cells vary depending on the cell types, only short epidermal cells (A and B cells covering parenchymatic mesophyll tissue) were evaluated for cellular phenotypes (Koga et al. 1990). Interactions were scored only when the conidium had developed a mature appressorium and host cells were attacked by a single conidium.

\section{$\mathrm{H}_{2} \mathrm{O}_{2}$ detection by DAB infiltration method.}

Detection of $\mathrm{H}_{2} \mathrm{O}_{2}$ was performed using a DAB infiltration method adapted from Thordal-Christensen and associates (1997). The first leaves from 7-day-old seedlings were inoculated on the adaxial surface with a spore density of 15 conidia per square $\mathrm{mm}$ and were incubated in the growth chamber. Inoculated leaves were infiltrated with $0.7 \mathrm{mg}$ of DAB per $\mathrm{ml}$ $(\mathrm{pH} 3.8$, adjusted with $\mathrm{HCl})$ and were incubated in the growth chamber for $2 \mathrm{~h}$ before fixation at indicated timepoints. Inoculated leaves were harvested and fixed at 18, 24, and 48 hai. Different patterns of DAB-staining were evaluated quantitatively. If more than one cellular structure stained with DAB at the same interaction site, the most intensively stained interaction was counted.

\section{Protein cross-linking by Coomassie blue staining.}

In order to visualize protein cross-linking in cell walls, we performed Coomassie blue staining as described by ThordalChristensen and associates (1997) with slight modification. Seven-day-old first leaves were inoculated on the adaxial surface. At specific timepoints, inoculated leaves were fixed and cleared in $0.15 \%$ trichloroacetic acid (wt/vol) in ethyl alcohol/chloroform (4:1; vol/vol) (Hückelhoven and Kogel 1998), then shook in $1 \% \mathrm{SDS}$ at $80^{\circ} \mathrm{C}$ for $24 \mathrm{~h}$ to remove unbound proteins. Subsequently, leaves were stained at $90^{\circ} \mathrm{C}$ for $30 \mathrm{~min}$ in $0.1 \%$ Coomassie brilliant blue (in $40 \%$ ethanol and $10 \%$ acetic acid) and were destained in a solution of $40 \%$ ethanol and $10 \%$ acetic acid at $90^{\circ} \mathrm{C}$ for $10 \mathrm{~min}$. The samples were examined by light microscopy.

\section{Determination of SA.}

Total SA was extracted and quantified following the protocol described by Hückelhoven and associates (1999). First-leaf tissue samples were ground to a fine powder in liquid nitrogen, and $0.4 \mathrm{~g}$ of leaf powder (fresh weight) each in three replicates from the pool was used for sample preparation. SA was determined by fluorescence (excitation $298 \mathrm{~nm}$, emission $400 \mathrm{~nm}$ ) after separation on a C18 reverse phase HPLC (high-pressure liquid chromatography) column (LiChroCart 250-4, LiChrosphere C18, $5 \mu \mathrm{m}$; Merck, Darmstadt, Germany) using a trichloro acetic acid and methanol gradient. The SA content in the sample extracts was corrected for the recovery of internal standard (O-methoxy benzoic acid) (Meuwly and Métraux 1993).

\section{RNA extraction and gene expression analyses.}

Total RNA was extracted from first leaves using an RNA extraction buffer, peqGold RNAPure, according to the manufacturer's instructions (Peqlab Biotechnology GmbH, Erlangen, Germany). RNA concentrations were determined spectrophotometrically. For Northern analysis, $10 \mu \mathrm{g}$ of total RNA from each sample of green leaves and $5 \mu \mathrm{g}$ from white leaves were fractionated by electrophoresis on denaturating agarose gels. Ethidium bromide staining revealed similar amounts of total RNA in samples from green and white leaves, as judged by the intensities of the bands representing $25 \mathrm{~S}$ and $18 \mathrm{~S}$ rRNAs (Zubko and Day 2002). 23S and 16S rRNA bands were not detectable in the white leaves, as they are deficient in plastid ribosomal RNAs. These gels were blotted by capillary transfer to positively charged nylon membranes. The RNA was crosslinked under UV light. Membranes were hybridized under stringent conditions in Dig Easy Hyb buffer (Roche, Mannheim, Germany) with digoxigenin or fluorescein labeled probes. Immunodetection of transcript with chemiluminescence was performed after two stringent washes for $20 \mathrm{~min}$ in $0.1 \times \mathrm{SSC}(1 \times$ $\mathrm{SSC}$ is $0.15 \mathrm{M} \mathrm{NaCl}$ plus $0.015 \mathrm{M}$ sodium citrate), $0.1 \% \mathrm{SDS}$ according to manufacturer's protocols for anti-digoxigenin- or anti-fluorescein-AP, Fab fragments, and CDP-Star (Roche, Mannheim, Germany). Plasmids containing cDNAs from PRIb (Bryngelsson et al. 1994), PAL (GenBank accession number AJ427587; K.-H. Kogel, unpublished data), 14-3-3 (GenBank accession number P29305; Brandt et al. 1992), and OXLP, BI-1, and Asprot (Hückelhoven et al. 2001) were used for generating antisense digoxigenin-labeled RNA probes for Northern analysis.

RT-PCR was performed to analyze the expression of MLO, APX, pNAox, and GDI. Based on the EST sequence AJ000240 (Hess et al. 1998), a full-length cDNA clone for a barley GDI was isolated and sequenced during the course of this study (GenBank accession number AY346010)). First leaves from white and green leaves at $0,3,6,12,24$, and $48 \mathrm{~h}$ from mockinoculated and inoculated plants were harvested, and total RNA was extracted. The RNA was reverse transcribed in a $20-\mu \mathrm{l}$ reaction using the SuperScript cDNA synthesis kit (Invitrogen. Karlsruhe, Germany). Equal amounts of RNA from green and white leaves (4 and $2 \mu \mathrm{g}$, respectively, resulted in equal amounts of mRNA, as judged by ethidium bromide staining) were used to synthesize first strand cDNA by using Superscript II reverse transcriptase and oligo(dT) in the presence of ribonuclease inhibitor. After annealing at $42^{\circ} \mathrm{C}, 200$ units of Superscript II reverse transcriptase was added, and the reaction was left for $50 \mathrm{~min}$ at $42^{\circ} \mathrm{C}$, followed by inactivation of the enzyme at $70^{\circ} \mathrm{C}$ for $15 \mathrm{~min}$. Expression levels of these genes was determined using $1 \mu \mathrm{l}$ of cDNA from each sample for PCR amplification with the gene-specific primers in $25 \mu \mathrm{l}$ of PCR reaction. For putative barley $p N A o x$ and for barley $c A P X$, primers described in Hückelhoven and associates (2001) were used. Primer pairs 5'-CAGCTGCACGTCTTCATCTT-3' and 5'-AAATCTGCACTGGGGATGTC-3' for the 1,200-bp-long Mlo fragment (Büschges et al. 1997) and 5'-CACCCCCTGC AAATATAGGA-3' and 5'-AATTCGACCTTGCACTCTGG-3' to obtain the 601-bp fragment of GDI (Hess et al. 1998) were used. Barley ubiquitin (GenBank accession number M60175) was used as a control for constitutive gene expression, primers for which were 5'-CCAAGATGCAGATCTTCGTGA-3' (5' primer) and 5'-TTCGCGATAGGTAAAAGAGCA-3' (3' primer) for a 513-bp fragment.

\section{ACKNOWLEDGMENTS}

This work was supported by the Deutsche Forschungsgemeinschaft (DFG), grant Ko 1208/6, the Deutsche Akademische Auslandsdienst (DAAD) and BASF AG.

\section{LITERATURE CITED}

Bogdanove, A. J., and Martin, G. B. 2000. AvrPto-dependent Pto-interacting proteins and AvrPto-interacting proteins in tomato. Proc. Natl. Acad. Sci. U.S.A. 97:8836-8840.

Boyd, L. A., Smith, P. H., Green, R. M., and Brown, J. K. M. 1994. The relationship between the expression of defense-related genes and mildew development in barley. Mol. Plant-Microbe Interact. 7:401-410.

Bradley, D. J., Kjellbom, P., and Lamb, C. J. 1992. Elicitor- and woundinduced oxidative cross-linking of a proline-rich plant cell wall protein: A novel, rapid defence response. Cell 70:21-30.

Brandt, J., Thordal-Christensen, H., Vad, K., Gregersen, P. L., and Collinge, D. B. 1992. A pathogen-induced gene of barley encodes a 
protein showing high similarity to a protein kinase regulator. Plant $\mathrm{J}$. 2:815-820.

Burhenne, K., and Gregersen, P. L. 2000. Up-regulation of the ascorbatedependent antioxidative system in barley leaves during powdery mildew infection. Mol. Plant Pathol.1:303-314.

Bryngelsson, T., Sommer-Knudsen, J., Gregersen, P. L., Collinge, D. B., Ek, B., and Thordal-Christensen, H. 1994. Purification, characterization, and molecular-cloning of basic Pr-1-type pathogenesis-related proteins from barley. Mol. Plant-Microbe Interact. 7:267-275.

Büschges, R., Hollricher, K., Panstruga, R., Simons, G., Wolter, M., Frijters, A., van Daelen, R., van der Lee, T., Diergaarde, P., Groenendijk, J., Töpsch, S., Vos, P., Salamini, F., and Schulze-Lefert, P. 1997. The barley Mlo gene: A novel control element of plant pathogen resistance. Cell 88:695-705.

Clark, T. A., Zeyen, R. J., Smith, A. G., Carver, T. L. W., and Vance, C. P. 1994. Phenylalanine ammonia lyase mRNA accumulation, enzyme activity and cytoplasmic responses in barley isolines, differing at $M l-a$ and Ml-o loci, attacked by Erysiphe graminis f. sp. hordei. Physiol. Mol. Plant Pathol. 44:171-185.

Collins, N. C., Thordal-Christensen, H., Lipka, V., Bau, S., Kombrink, E., Qiu, J.-L., Hückelhoven, R., Stein, M., Freialdenhoven, A., Somerville, S. C., and Schulze-Lefert, P. 2003. SNARE-protein-mediated disease resistance at the plant cell wall. Nature 425:973-977.

Cooper, B., Clarke, J. D., Budworth, P., Kreps, J., Hutchison, D., Park, S., Guimil, S., Dunn, M., Luginbühl, P., Ellero, C., Goff, S. A., and Glazebrook, J. 2003. A network of rice genes associated with stress response and seed development. Proc. Natl. Acad. Sci. U.S.A. 100:4945-4950.

Dixon, R. A., and Paiva, N. L. 1995. Stress-induced phenylpropanoid metabolism. Plant Cell 7:1085-1097.

Finnie, C., Andersen, C. H., Borch, J., Gjetting, S., Christensen, A. B., de Boer, A. H., Thordal-Christensen, H., and Collinge, D. B. 2002. Do 14 3-3 proteins and plasma membrane $\mathrm{H}^{+}$-ATPases interact in the barley epidermis in response to the barley powdery mildew fungus? Plant Mol. Biol. 49:137-147.

Finnie, C., Borch, J., and Collinge, D. B. 1999. 14-3-3 proteins: Eukaryotic regulatory proteins with many functions. Plant Mol. Biol. 40:545-554

Grant, J. J., and Loake, G. J. 2000. Role of reactive oxygen intermediates and cognate redox signaling in disease resistance. Plant Physiol. 124:21-29.

Gregersen, P. L., Thordal-Christensen, H., Förster, H., and Collinge, D. B. 1997. Differential gene transcript accumulation in barley leaf epidermis and mesophyll in response to attack by Blumeria graminis f. sp. hordei (syn. Erysiphe graminis f. sp. hordei). Physiol. Mol. Plant Pathol. 51:85-97.

Hagemann, R., and Scholz, F. 1962. Ein Fall geninduzierter Mutationen des Plasmotypus bei Gerste. Der Züchter 32:50-59.

Hess, W. R., Golz, R., and Börner, T. 1998. Analysis of randomly selected cDNAs reveals the expression of stress- and defense-related genes in the barley mutant albostrians. Plant Sci. 133:191-201.

Hess, W. R., Hübschmann, T., and Börner, T. 1994a. Ribosome-deficient plastids of albostrians barley: Extreme representatives of non-photosynthetic plastids. Endocyt. Cell Res. 10:65-80.

Hess, W. R., Müller, A., Nagy, F., and Börner, T. 1994b. Ribosomedeficient plastids affect transcription of light-induced nuclear genes: Genetic evidence for a plastid- derived signal. Mol. Gen. Genet. 242:305-312.

Hess, W. R., Schendel, R., Rüdiger, W., Fieder, B., and Börner, T. 1992. Components of chlorophyll biosynthesis in a barley albino mutant unable to synthesize D-aminolevulinic acid by utilizing the transfer RNA for glutamic acid. Planta $188: 19-27$.

Hückelhoven, R., and Kogel, K.-H. 1998. Tissue-specific superoxide generation at interaction sites in resistant and susceptible near-isogenic barley lines attacked by the powdery mildew fungus (Erysiphe graminis f. sp. hordei). Mol. Plant-Microbe Interact. 11:292-300.

Hückelhoven, R., and Kogel, K.-H. 2003. Reactive oxygen intermediates in plant-microbe interactions: Who is who in powdery mildew resistance? Planta 216:891-902.

Hückelhoven, R., Fodor, J., Preis, C., and Kogel, K.-H. 1999. Hypersensitive cell death and papilla formation in barley attacked by the powdery mildew fungus are associated with $\mathrm{H}_{2} \mathrm{O}_{2}$ but not with salicylic acid accumulation. Plant Physiol. 119:1251-1260.

Hückelhoven, R., Dechert, C., Trujillo, M., and Kogel, K.-H. 2001. Differential expression of putative cell death regulator genes in near-isogenic, resistant and susceptible barley lines during interaction with the powdery mildew fungus. Plant Mol. Biol. 47:739-748.

Hückelhoven, R., Dechert, C., and Kogel, K.-H. 2003. Overexpression of barley Bax inhibitor 1 induces breakdown of mlo-mediated penetration resistance to Blumeria graminis. Proc. Natl. Acad. Sci. U.S.A.
100:5555-5560

Jarosch, B., Kogel, K.-H., and Schaffrath, U. 1999. The ambivalence of the barley Mlo locus: Mutations conferring resistance against powdery mildew (Blumeria graminis f. sp. hordei) enhance susceptibility to the rice blast fungus Magnaporthe grisea. Mol. Plant-Microbe Interact. 12:508-514.

Jespersen, H. M., Kjaersgard, I. V. H., Ostergaard, L., and Welinder, K. G. 1997. From sequence analysis of three novel ascorbate peroxidases from Arabidopsis thaliana to structure, function and evolution of seven types of ascorbate peroxidase. Biochem. J. 326:305-310.

Kawai, M., Pan, L., Reed, J.C., and Uchimiya, H. 1999. Evolutionally conserved plant homologue of the Bax inhibitor-1 (BI-1) gene capable of suppressing Bax-induced cell death in yeast. FEBS (Fed. Eur. Biochem. Soc.) Lett. 464:143-147.

Kim, M. C., Panstruga, R., Elliott, C., Müller, J., Devoto, A., Yoon, H. W., Park, H. C., Cho, M. J., and Schulze-Lefert, P. 2002. Calmodulin interacts with MLO protein to regulate defence against mildew in barley. Nature 416:447-450.

Kim, W. Y., Kim, C. Y., Cheong, N. E., Choi, Y. O., Lee, K. O., Lee, S.-H., Park, J. B., Nakano, A., Bahk, J. D., Cho, M. J., and Lee, S. Y. 1999. Characterization of two fungal-elicitor-induced rice cDNAs encoding functional homologues of the rab-specific GDP-dissociation inhibitor. Planta 210:143-149.

Koga, H., Bushnell, W. R., and Zeyen, R. J. 1990. Specificity of cell type and timing of events associated with papilla formation and the hypersensitive reaction in leaves of Hordeum vulgare attacked by Erysiphe graminis f. sp. hordei. Can. J. Bot. 68:2344-2352.

Kumar, J., Hückelhoven, R., Beckhove, U., Nagarajan, S., and Kogel, K.H. 2001. A compromised Mlo pathway affects the response of barley to the necrotrophic fungus Bipolaris sorokiniana (teleomorph: Cochliobolus sativus) and its toxins. Phytopathology 91:127-133.

Levine, A., Tenhaken, R., Dixon, R. A., and Lamb, C. J. 1994. $\mathrm{H}_{2} \mathrm{O}_{2}$ from the oxidative burst orchestrates the plant hypersensitive disease resistance response. Cell 79:583-593.

Meuwly, P., and Métraux, J.-P. 1993. Ortho-anisic acid as internal standard for the simultaneous quantitation of SA and its putative biosynthetic precursors in cucumber leaves. Anal. Biochem. 214:500-505.

Mittler, R., Feng, X., and Cohen, M. 1998. Post-transcriptional suppression of cytosolic ascorbate peroxidase expression during pathogeninduced programmed cell death in tobacco. Plant Cell 10:461-473.

Nashaat, N. I., and Moore, K. 1992. Resistance responses of albino leaves of Triticum timopheevii mutants inoculated with Erysiphe graminis $\mathrm{f}$. sp. tritici. Plant Pathol. 41:25-28.

Nawrath, C., and Métraux, J.-P. 1999. Salicylic acid induction-deficient mutants of Arabidopsis express $P R-2$ and $P R-5$ and accumulate high levels of camalexin after pathogen inoculation. Plant Cell 11:13931404.

Peng, M., and Kuc, J. 1992. Peroxidase-generated hydrogen peroxide as a source of antifungal activity in vitro and on tobacco leaf discs. Phytopathology 82:696-699.

Piffanelli, P., Zhou, F., Casais, C., Orme, J., Jarosch, B., Schaffrath, U., Collins, N.C., Panstruga, R., and Schulze-Lefert, P. 2002. The barley MLO modulator of defense and cell death is responsive to biotic and abiotic stress stimuli. Plant Physiol. 129:1076-1085

Pfeffer, S. R., Dirac-Svejstrup, A. B., and Soldati, T. 1995. Rab GDP dissociation inhibitor: Putting Rab GTPases in the right place. J. Biol Chem. 270:17057-17059.

Roberts, M. R. 2003. 14-3-3 proteins find new partners in plant cell signaling. Trends Plant Sci. 8:218-223.

Runeberg-Roos, P., and Saarma, M. 1998. Phytepsin, a barley vacuolar aspartic proteinase, is highly expressed during autolysis of developing tracheary elements and sieve cells. Plant J. 15:139-145.

Sanchez, P., de Torres Zabala, M., and Grant, M. 2000. AtBI-1, a plant homologue of Bax inhibitor-1, suppresses Bax-induced cell death in yeast and is rapidly up-regulated during wounding and pathogen challenge. Plant J. 21:393-399.

Sano, H., and Ohashi, Y. 1995. Involvement of small GTP-binding proteins in defense signal-transduction pathways of higher plants. Proc. Natl. Acad. Sci. U.S.A. 92:4138-4144

Santamaria, M., Thomson, C. J., Read, N. D., and Loake, G. J. 2001. The promoter of a basic PR1-like gene, AtPRB1, from Arabidopsis establishes an organ-specific expression pattern and responsiveness to ethylene and methyl jasmonate. Plant Mol. Biol. 47:641-652.

Schäfer, P., Hückelhoven, R., and Kogel K.-H. 2004. The white barley mutant albostrians shows a super-susceptible but symptomless interaction phenotype with the hemibiotrophic fungus Bipolaris sorokiniana. Mol. Plant-Microbe Interact. 17:366-373.

Schultheiss, H., Dechert, C., Király, L., Fodor, J., Michel, K., Kogel, K.H., and Hückelhoven, R. 2003. Functional assessment of the pathogenesis-related protein PR1b in barley. Plant Sci. 165:1275-1280. 
Schweizer, P., Christoffel, A., and Dudler, R. 1999. Transient expression of members of the germin-like gene family in epidermal cells of wheat confers disease resistance. Plant J. 20:541-552.

Shah, J. 2003. The salicylic acid loop in plant defense. Curr. Opin. Plant Biol. 6:365-371.

Shioji, T., Toyoda, H., and Shishiyama, J. 1982. Resistance responses in albino leaves of barley inoculated with Erysiphe graminis f. sp. hordei. Phytopathol. Z. 104:255-263.

Thordal-Christensen, H., Zhang, Z., Wei, Y., and Collinge, D. B. 1997. Subcellular localization of $\mathrm{H}_{2} \mathrm{O}_{2}$ in plants. $\mathrm{H}_{2} \mathrm{O}_{2}$ accumulation in papillae and hypersensitive response during the barley-powdery mildew interaction. Plant J. 11:1187-1194.

Ueda, T., Yoshizumi, T., Anai, T., Matsui, M., Uchimiya, H., and Nakano, A. 1998. AtGDI2, a novel Arabidopsis gene encoding a Rab GDP dissociation inhibitor. Gene 206:137-143.

Vallelian-Bindschedler, L., Métraux, J.-P., and Schweizer, P. 1998. Salicylic acid accumulation in barley is pathogen specific but not required for defense-gene activation. Mol. Plant-Microbe Interact. 11:702-705.

Vernoud, V., Horton, A. C., Yang, Z., and Nielsen, E. 2003. Analysis of the small GTPase gene superfamily of Arabidopsis. Plant Physiol.
131:1191-1208.

Wei, Y., Zhang, Z., Andersen, C. H., Schmelzer, E., Gregersen, P. L., Collinge, D. B., Smedegaard-Petersen, V., and Thordal-Christensen, H. 1998. An epidermis/papilla-specific oxalate oxidase-like protein in the defense response of barley attacked by the powdery mildew fungus. Plant Mol. Biol. 36:101-112.

Wiberg, A. 1974. Genetical studies of spontaneous sources of resistance to powdery mildew in barley. Hereditas 77:89-148.

Wu, G., Short, B. J., Lawrence, E. B., Leon, J., Fitzsimmons, K. C. Levine, E. B., Raskin, I., and Shah, D. M. 1997. Activation of host defense mechanisms by elevated production of $\mathrm{H}_{2} \mathrm{O}_{2}$ in transgenic plants. Plant Physiol. 115:427-435.

Zhou, F., Andersen, C. H., Burhenne, K., Fischer, P. H., Collinge, D. B., and Thordal-Christensen, H. 2000. Proton extrusion is an essential signaling component in the HR of epidermal single cells in the barleypowdery mildew interaction. Plant J. 23:245-254.

Zubko, M. K., and Day, A. 2002. Differential regulation of genes transcribed by nucleus-encoded plastid RNA polymerase, and DNA amplification, within ribosome-deficient plastids in stable phenocopies of cereal albino mutants. Mol. Genet. Genomics 267:27-37. 